\title{
Membrane foulants characterization in a membrane bioreactor (MBR) treating hypersaline oily wastewater.
}

\begin{abstract}
This study focused on the characterization of fouling cake layer during operation of a membrane bioreactor system employed for the treatment of synthetic hypersaline oily wastewater. Also the effects of ultrasound and addition of four types of flocculants (aluminium sulfate, Chitosan, ferric chloride, polyaluminium chloride) on mitigation of membrane fouling were studied. The components of the foulants were examined by Fourier transform infrared (FTIR) spectroscopy, scanning electron microscopy (SEM), atomic force microscopy (AFM), energy dispersive X-ray (EDX) analysis, inductively coupled plasma (ICP) and particle size analyzer (PSA). The FTIR demonstrated that membrane fouling layer is governed by the deposition of organic and inorganic substances composed of extracellular polymeric substances (EPS) (proteins, polysaccharides, etc.), hydrocarbon components and inorganic matters. The AFM images of the fouled membrane confirmed the idea of surface coverage as a fouling mechanism. The SEM analysis showed that rod-shape bacterial clusters were one of the contributors to membrane cake layer. The EDX and ICP results showed that $\mathrm{Mg}, \mathrm{Al}, \mathrm{Ca}, \mathrm{Na}, \mathrm{K}$ and $\mathrm{Fe}$ were the major metal elements in the fouling cake. The PSA results indicate that membrane foulants had a much smaller size than mixed liquor suspensions in the MSBR. Fouling mitigation experiments showed that the effect of organic flocculant was more than inorganic chemicals but the overall effects were not significant. Ultrasound could effectively remove the fouling cake from the membrane surface and thus recovered the membrane permeation flux for a long time.
\end{abstract}

Keyword: Membrane fouling; Hypersaline oily wastewater; Membrane bioreactor; Foulant characterization. 